\title{
Faktor Risiko Mortalitas pada Anak dengan Syok di Ruang Perawatan Intensif Rumah Sakit dr. Moewardi Surakarta
}

Karmono Sutadi, Pudjiastuti, Sri Martuti

Bagian Ilmu Kesehatan Anak Fakultas Kedokteran Universitas Sebeblas Maret/RSUD Dr. Moewardi, Surakarta

Latar belakang. Syok merupakan sepertiga penyebab mortalitas anak di ruang rawat intensif anak. Penelitian mengenai faktor risiko mortalitas pasien anak dengan syok di ruang rawat intensif anak memiliki hasil bervariasi.

Tujuan. Menganalisis faktor risiko mortalitas pasien anak dengan syok di ruang perawatan intensif rumah sakit dr. Moewardi Surakarta. Metode. Penelitian dilakukan di rumah sakit dr. Moewardi Surakarta pada bulan Agustus 2018 dengan data rekam medis pasien antara Juli 2016 hingga Juli 2018. Subjek dilakukan penilaian karakteristik berupa usia, jenis syok, skor PRISM III, skor vasoaktifinotropik, ventilasi mekanik, fluid overload, dan mortalitas.

Hasil. Didapatkan 70 subjek yang memenuhi kriteria inklusi. Mortalitas pasien anak dengan syok adalah $71,4 \%$. Hasil analisis bivariat menunjukkan usia $<1$ tahun memiliki risiko mortalitas 5,52 (95\% CI 1,15-26,48) p=0,02. Sementara jenis syok sepsis memiliki OR 4,83(95\% CI 1,26-18,58) p=0,02; skor vasoaktif-inotropik $\geq 20$ memiliki OR 6,00 (95\% CI 1,94-18,60) p=0,01; skor PRISM III $\geq 8$ memiliki OR 9,75 (95\% CI 2,97-32,10) p 0,00; fluid overload $\geq 10 \%$ memiliki OR 5,67 (95\% CI 1,47-1,88) p=0,01. Hasil tidak signifikan didapatkan pada kebutuhan bantuan ventilasi mekanis dengan nilai OR 1,17 (95\% CI 0,42-3,32) dan nilai p=0,76. Hasil analisis multivariat menunjukkan fluid overload $\geq 10 \%$, skor PRISM III $\geq 8$ dan skor vasoaktif-inotropik $\geq 20$ memiliki nilai OR (95\%CI) berturut-turut 10,82 (1,59-73,43); 32,86 (3,01-358,36); dan 57,84 (3,80-881,50) dengan nilai $\mathrm{p}<0,05$.

Kesimpulan. Usia $>1$ tahun, syok septik, skor vasoaktif-inotropik $\geq 20$, skor PRISM III $\geq 8$, fluid overload $\geq 10 \%$ merupakan faktor risiko mortalitas pasien anak dengan syok. Sari Pediatri 2020;22(1):7-12

Kata kunci: syok, anak, faktor risiko, mortalitas

\section{Risk Factors for Mortality in Children with Shock in the Hospital Intensive Care Room dr. Moewardi Surakarta}

Karmono Sutadi, Pudjiastuti, Sri Martuti

Background. The shock was one third mortality cause in children who admitted to intensive care. Research in this area has varied results. Objective. To analyze the mortality risk factors in pediatric patients with shock in the hospital intensive care room dr. Moewardi Surakarta.

Methods. The study was conducted at dr. Moewardi hospital Surakarta in August 2018 with secondary data (a medical record) taken from July 2016 to July 2018. Research subjects were 70 patients, taken consecutively according to inclusion criteria. Subjects were assessed for characteristics such as age, type of shock, PRISM III score, vasoactive-inotropic score, mechanical ventilation, fluid overload, and mortality.

Result. There were 70 subjects who met the inclusion criteria. The mortality of pediatric patients with shock was $71.4 \%$. The results of bivariate analysis showed that age $<1$ year in pediatric patients with shock had a mortality risk of 5.52 (95\% CI 1.15-26.48) $\mathrm{p}=0.02$. Whereas, septic shock had OR values of 4.83 (95\% CI 1.26-18.58) $\mathrm{p}=0.02$; vasoactive-inotropic score $\geq 20$ had OR values of 6.00 (95\% CI 1.94-18.60) p 0.01; PRISM III score $\geq 8$ had OR values of 9.75 (95\% CI 2.97-32.10) p 0.00; fluid overload $\geq 10 \%$ has OR values of 5.67 (95\% CI 1.47-1.88) p=0.01. Insignificant results were obtained for the need for mechanical ventilation with an OR value of 1.17 (95\% CI 0.42-3.32) p=0.76. The results of multivariate analysis showed fluid overload $\geq 10 \%$, PRISM III score $\geq 8$, and vasoactive-inotropic score $\geq 20$ had OR values (95\% CI) respectively 10.82 (1.59-73.43); 32.86 (3.01-358.36); and 57.84 (3.80-881.50) all have $\mathrm{p}<0.05$.

Conclusion. Age $<1$ year, septic shock, vasoactive-inotropic score $\geq 20$, PRISM III score $\geq 8$, fluid overload $\geq 10 \%$ are mortality risk factors in pediatric patients with shock.Sari Pediatri 2020;22(1):7-12

Keywords: shock, children, risk factors, mortality

Alamat korespondensi: Karmono Sutadi. Bagian Ilmu Kesehatan Anak Fakultas Kedokteran Universitas Sebelas Maret Surakarta. Jl. Kolonel Sutarto No.132, Jebres, Jebres, Kota Surakarta, Jawa Tengah 57126. Telpon/Fax. Email: karmono.sutadi@gmail.com 
S yok merupakan sepertiga penyebab mortalitas anak di ruang rawat intensif. ${ }^{1,2}$ Penelitian melaporkan tingkat mortalitas syok sepsis , 4060\% dan syok kardiogenik , 60\%. ${ }^{3,4}$ Penelitian lain mendapatkan penyebab mortalitas dan morbiditas anak terbanyak adalah syok hipovolemik. ${ }^{5}$ Syok sepsis dikaitkan dengan tingginya mortalitas, sedangkan syok hipovolemik berhubungan dengan mortalitas yang rendah. ${ }^{6}$ Penelitian Mbevi $\mathrm{dkk}^{7}$ menyatakan syok hipovolemik memiliki mortalitas yang tinggi karena diare/dehidrasi dan memiliki case fatility rate paling tinggi.

Penelitian mengenai faktor risiko mortalitas anak dengan syok di ruang perawatan intensif memiliki hasil bervariasi. Kaur $\mathrm{dkk}^{8}$ melaporkan mortalitas anak dengan sepsis, sepsis berat, dan syok sepsis tidak dipengaruhi oleh usia, keterlambatan mendapat perawatan di PICU, lama rawat, disfungsi multiorgan, dan skor PRISM III. Chang $\mathrm{dkk}^{9}$ menyatakan bahwa usia $<1$ tahun memiliki luaran yang buruk. Rusmawatiningtyas dan Nurnaningsih ${ }^{10}$ mendapatkan hasil yang berbeda bahwa fluid overload $\geq 10 \%$ dan kebutuhan ventilasi mekanis dalam 24 jam meningkatkan risiko mortalitas pada pasien syok sepsis. Kim dkk ${ }^{11}$ menyatakan fluid overload tidak berhubungan dengan kelangsungan hidup pasien tanpa sepsis. Bramantyo ${ }^{12}$ melaporkan skor PRISM III $\geq 8$ memiliki mortalitas 10 kali lipat dibandingkan dengan skor PRISM III $<8$.

Haque dkk ${ }^{13}$ melaporkan tingginya skor vasoaktif-inotropik pada syok sepsis berhubungan dengan tingginya mortalitas. McIntosh $\mathrm{dkk}^{14}$ menyatakan skor vasoaktif-inotropik berhubungan dengan lama rawat PICU dan lama penggunaan ventilator, tetapi henti jantung, dan mortalitas tidak konsisten berhubungan dengan skor vasoaktif-inotropik yang tinggi.

Berdasarkan perbedaan hasil penelitian di atas, terdapat beberapa variabel yang dapat dijadikan sebagai prediktor mortalitas pada pasien anak dengan syok, antara lain, usia, jenis syok, skor PRISM III, skor vasoaktif-inotropik, ventilasi mekanik, dan fluid overload. Pengenalan faktor mortalitas tersebut dapat menilai prognosis pasien anak dengan syok di ruang perawatan intensif. Tujuan penelitian ini adalah untuk menganalisis variabel usia, jenis syok, skor PRISM III, skor vasoaktif-inotropik, ventilasi mekanik, dan fluid overload sebagai faktor risiko mortalitas pada anak dengan syok di ruang perawatan intensif anak.

\section{Metode}

Rancangan penelitian ini adalah potong lintang. Sampel didapat dari data rekam medis pasien anak dengan syok yang dirawat di ruang perawatan intensif anak (PICU dan HCU anak) KSM Ilmu Kesehatan Anak FK UNS/RSUD dr. Moewardi Surakarta antara Juli 2016 hingga Juli 2018. Kriteria inklusi pada penelitian ini adalah pasien anak berusia 1 bulan hingga 18 tahun, terdiagnosis syok pada rekam medis serta dirawat di HCU anak dan PICU Rumah Sakit dr. Moewardi. Pasien dengan data rekam medis tidak lengkap dieksklusikan dari penelitian ini. Penelitian ini telah memperoleh kelaikan etik dari Komisi Etik Penelitian Kesehatan RSUD dr. Moewardi Fakultas Kedokteran Universitas Sebelas Maret, Surakarta.

Data yang diambil meliputi nama pasien, jenis kelamin, usia, diagnosis, tingkat kesadaran, laju nadi, tekanan darah, laju napas, tanda hipoperfusi jaringan, kadar hemoglobin, jenis syok, kadar PT/APTT, kadar kalium serum, kadar kalsium serum, bilirubin total, kadar gula darah, PF rasio, $\mathrm{PCO} 2, \mathrm{HCO}$, diuresis, resusitasi cairan, inotropik, vasoaktif, lama rawat PICU/HCU, ventilasi mekanik, kondisi keluar HCU/ PICU. Data tersebut dimasukkan ke dalam program perangkat lunak $\operatorname{SPSS}^{\oplus} 20.0$, dan diolah dengan analisis multivariat regresi logistik untuk menilai prediktor mortalitas dari variabel bebas. Variabel bivariat dengan $\mathrm{p}<0,20$ atau merupakan variabel yang berhubungan dengan variabel terikat dapat dimasukan dalam model multivariat. Tingkat kemaknaan dalam penelitian ini dinyatakan bila $\mathrm{p}<0,05$.

\section{Hasil}

Subyek penelitian sebanyak 70 orang yang sesuai dengan kriteria inklusi. Usia $\geq 1$ tahun sebesar $70 \%$, jenis syok paling banyak adalah syok sepsis $26(37,1 \%)$ subjek, membutuhkan bantuan ventilasi mekanis 37 $(52,9 \%)$, skor vasoaktif-inotropik $\geq 2048$ (68,6\%), skor PRISM III $\geq 849$ (70\%), dan fluid overload $<10 \%$ $42(60 \%)$. Karakteristik sampel dari penelitian ini tertera pada Tabel 1 .

Analisis bivariat mendapatkan hasil usia $<1$ tahun pada pasien anak dengan syok memiliki OR 5,52 (95\% CI $1,15-26,48) \mathrm{p}=0,02$. Jenis syok sepsis memiliki OR $4,83(95 \%$ CI $1,26-18,58) \mathrm{p}=0,02$. Skor vasoaktifinotropik $\geq 20$ memiliki OR 6,00 (95\% CI 1,94- 
Tabel 1. Data karakteristik subjek penelitian

\begin{tabular}{lcc}
\hline Variabel & F & $\%$ \\
\hline Usia (tahun) & & \\
$\quad<1$ & 21 & 30,0 \\
$\quad 1$ & 49 & 70,0 \\
Jenis syok & & \\
$\quad$ Hipovolemik & 21 & 30,0 \\
$\quad$ Kardiogenik & 23 & 32,9 \\
$\quad$ Sepsis & 26 & 37,1 \\
Ventilasi mekanis & & \\
$\quad$ Ya & 37 & 52,9 \\
$\quad$ Tidak & 33 & 47,1 \\
Skor vasoaktif-inotropik & & \\
$\quad \geq 20$ & 48 & 68,6 \\
$\quad<20$ & 22 & 31,4 \\
Skor_PRISM III & & \\
$\quad \geq 8$ & 49 & 70,0 \\
$\quad<8$ & 21 & 30,0 \\
Fluid_overload & & \\
$\quad \geq 10 \%$ & 28 & 40,0 \\
$<10 \%$ & 42 & 60,0 \\
Mortalitas & & \\
$\quad$ Meninggal & 50 & 71,4 \\
Hidup & 20 & 28,6 \\
\hline
\end{tabular}

18,60) $\mathrm{p}=0,01$. Skor PRISM III $\geq 8$ memiliki OR 9,75 (95\% CI 2,97-32,10) $\mathrm{p}=0,00$. Fluid overload $\geq 10 \%$ memiliki OR 5,67 (95\% CI 1,47-21,88) p=0,01. Hasil tidak signifikan didapatkan pada kebutuhan bantuan ventilasi mekanis dengan nilai OR 1,17 (95\% CI $0,42-3,32) \mathrm{p}=0,67$. Data analisis bivariat tertera pada Tabel 2.

Variabel bivariat usia, jenis syok, skor vasoaktifinotropik, skor PRISM III dan fluid overload diikutsertakan dalam analisis multivatiat. Hasil analisis multivariat regresi logistik menunjukkan variabel yang berpengaruh secara signifikan terhadap mortalitas secara berurutan adalah fluid overload ( $\mathrm{p} 0,01$ ), diikuti skor PRISM III (p 0,01) dan skor vasoaktif-inotropik (p 0,02). Data analisis multivariat tertera pada Tabel 3.

\section{Pembahasan}

Hasil penelitian menunjukkan usia $<1$ tahun berisiko 5,52 kali terhadap mortalitas pada anak dengan syok. Usia dapat berperan dalam peningkatan mortalitas. Pada anak, curah jantung lebih bargantung pada denyut jantung dibanding stroke volume karena miokard

Tabel 2. Analisis bivariat hubungan usia, syok, penggunaan ventilasi mekanis, skor vasoaktf inotropik, skor PRISM III dan fluid overload terhadap mortalitas

\begin{tabular}{|c|c|c|c|c|}
\hline \multirow{2}{*}{ Variabel } & \multicolumn{2}{|c|}{ Mortalitas } & \multirow{2}{*}{ OR $(95 \% \mathrm{CI})$} & \multirow{2}{*}{$\mathrm{P}$} \\
\hline & Meninggal & Hidup & & \\
\hline Usia (tahun) & & & $5,52(1,15-26,48)$ & 0,02 \\
\hline$<1$ & 19 & 2 & & \\
\hline$\geq 1$ & 31 & 18 & & \\
\hline Syok & & & $4,83(1,26-18,58)$ & 0,02 \\
\hline Syok sepsis & 23 & 3 & & \\
\hline Lainnya & 27 & 17 & & \\
\hline Ventilasi mekanis & & & $1,17(0,42-3,32)$ & 0,76 \\
\hline $\mathrm{Ya}$ & 27 & 10 & & \\
\hline Tidak & 23 & 10 & & \\
\hline Skor vasoaktif-inotropik & & & $6,00(1,94-18,60)$ & 0,01 \\
\hline$\geq 20$ & 40 & 8 & & \\
\hline$<20$ & 10 & 12 & & \\
\hline Skor_PRISM III & & & $9,75(2,97-32,10)$ & 0,00 \\
\hline$\geq 8$ & 42 & 7 & & \\
\hline$<8$ & 8 & 13 & & \\
\hline Fluid_overload & & & $5,67(1,47-21,79)$ & 0,01 \\
\hline$\geq 10 \%$ & 25 & 3 & & \\
\hline$<10 \%$ & 25 & 17 & & \\
\hline
\end{tabular}


Karmono Sutadi dkk: Faktor risiko mortalitas pada anak dengan syok

Tabel 3. Analisis multivariat hubungan usia, syok, skor vasoaktif-inotropik, skor PRISM III, dan fluid overload terhadap mortalitas

\begin{tabular}{lcc}
\hline Variabel & OR $(95 \%$ CI $)$ & P \\
\hline Usia & $4,18(0,49-35,87)$ & 0,19 \\
Syok sepsis & $4,01(0,55-29,21)$ & 0,17 \\
Skor vasoaktif-inotropik & $10,82(1,59-73,43)$ & 0,02 \\
Skor PRISM III & $32,86(3,01-358,36)$ & 0,01 \\
Fluid overload & $57,84(3,80-881,50)$ & 0,01 \\
\hline
\end{tabular}

belum berkembang sempurna, mekanisme kompensasi lebih bertumpu pada peningkatan denyut jantung sehingga mudah untuk terjadi fase dekompensasi. Fase tersebut mengakibatkan metabolisme energi yang tidak adekuat pada tingkat sel. Metabolisme sel tidak dapat menghasilkan energi yang cukup untuk homeostasis sel. Metabolisme ini akan menghasilkan hanya 2 molekul ATP per molekul glukosa dan laktat. Selanjutnya terjadi gangguan pompa ion membran sel, akumulasi natrium intraseluler, pengeluaran kalium dan akumulasi kalsium sitosol, sel membengkak, membran sel rusak, dan terjadi kematian sel. Kematian sel yang meluas menyebabkan gagal sistem multiorgan dan kematian. ${ }^{15}$

Hasil penelitian ini menunjukkan pasien dengan syok sepsis $88,5 \%$ meninggal. Secara statistik, syok sepsis berisiko 4,8 kali terhadap mortalitas pada anak dengan syok. Hasil uji chi-square menunjukkan adanya hubungan antara syok sepsis dengan kejadian mortalitas pada anak dengan syok. Hasil penelitian ini sejalan dengan beberapa penelitian sebelumnya yang melaporkan angka mortalitas syok sepsis sebesar $40-60 \%$. $^{3,4}$

Syok sepsis dikaitkan dengan mortalitas yang tinggi, sedangkan syok hipovolemik berhubungan dengan mortalitas yang rendah. ${ }^{6}$ Penelitian yang dilakukan oleh Rusmawatiningtyas dan Nurnaningsih ${ }^{10}$ menunjukkan syok sepsis memiliki angka mortalitas $88,2 \% .{ }^{10} \mathrm{Hal}$ ini terkait dengan keterlambatan pada deteksi dini anak dengan sakit kritis serta keterlambatan pemberian penanganan yang adekuat di ruang perawatan intensif karena keterlambatan merujuk pasien.Hasil dari penelitian ini menunjukkan bahwa penggunaan ventilator bukan merupakan variabel yang berhubungan dengan mortalitas pada anak dengan syok. Berdasarakan penelitian Medjo dkk, ${ }^{1}$ penyebab kematian pasien syok dengan penggunaan ventilasi mekanik lebih banyak dihubungkan dengan komplikasi penggunaannya. Komplikasi yang banyak terjadi adalah pneumonia berkaitan dengan ventilator, atelektasis, pneumotoraks, edema laring, dan kejadian ekstubasi. Penggunaan ventilasi mekanik bukan merupakan variabel yang meningkatkan mortalitas pada pasien anak dengan syok, mungkin hasil ini disebabkan karena komplikasi penggunaan ventilator mekanik jarang ditemukan di ruang perawatan intensif anak RS. dr. Moewardi.

Hasil penelitian kami menunjukkan bahwa pasien yang memiliki skor vasoaktif-inotropik $\geq 20$ berisiko 6 kali mengalami mortalitas pada anak dengan syok di ruang perawatan intensif anak. Hasil uji chi square juga menunjukkan adanya hubungan antara skor vasoaktifinotropik dengan kejadian mortalitas pada anak dengan syok. Penelitian McIntosh $\mathrm{dkk}^{14}$ menerangkan bahwa pasien dengan kebutuhan vasoaktif dan inotropik dalam 48 jam setelah masuk kemungkinan mengalami disfungsi organ multipel berkepanjangan yang meningkatkan durasi dan kebutuhan perawatan ruang intensif dan ventilasi. Hal tersebut secara tidak langsung dapat meningkatkan mortalitas pada pasien syok. Penelitian kami juga sejalan dengan penelitian Delgadodkk ${ }^{17}$ dan Haque A dkk. ${ }^{13}$ Hasil penelitian tersebut menyatakan bahwa penggunaan jumlah inotropik dan epinefrin pada hari pertama syok berhubungan dengan pasien meninggal dan skor vasoaktif-inotropik yang tinggi pada syok sepsis juga memiliki hubungan terhadap tingginya mortalitas.

Hasil statistik penelitian kami menyebutkan bahwa skor PRISM III $\geq 8$ berisiko 9,75 kali terjadi mortalitas pada anak dengan syok di ruang perawatan intensif anak Sejalan dengan itu, hasil penelitian Bramantyo ${ }^{12}$ melaporkan skor PRISM III $\geq 8$ memiliki mortalitas 10 kali lipat jika dibandingkan dengan skor PRISM III $<8$. Hasil penelitian memiliki hasil yang mirip dengan penelitian Bramantyo meskipun pada penelitian tersebut hanya meneliti pada pasien nonbedah, sedangkan dalam penelitian ini tidak mengeksklusikan pasien nonbedah. Hal tersebut menguatkan hasil bahwa PRISM III merupakan skoring yang dapat digunakan untuk memprediksi mortalitas pada pasien anak. 
Fluid overload sering dikaitkan dengan tingginya morbiditas dan mortalitas pasien sakit kritis yang berefek paling sering pada 2 sistem organ, yaitu paru-paru dan ginjal. Pada paru akan menyebabkan gangguan pertukaran gas, penurunan komplain paru, dan peningkatan usaha napas sehingga sering menyebabkan acute respiratory distress syndrome (ARDS). Sementara pada ginjal akan menyebabkan aliran darah ginjal menurun dan akan terjadi peningkatan tekanan interstisial, retensi natrium dan air, penurunan laju filtrasi glomerulus serta uremia berisiko terjadinya acute kidney injury (AKI). ${ }^{17}$ Gangguan kedua sistem organ ini yang menyebabkan kematian tersering akibat fluid overload. Pada penelitian ini ditemukan hubungan yang bermakna antara fluid overload dengan mortalitas. Fluid overload $\geq 10 \%$ pada pasien anak dengan syok memiliki risiko mortalitas 5,67 kali. Hasil penelitian ini sejalan dengan penelitian Rusmawatiningtyas dan Nurnaningsih ${ }^{10}$ (FO $>10 \%$ menyatakan risiko mortalitas pasien syok sepsis yang mengalami fluid overload $\geq 10 \%$ sebesar 6,69 kali.

Variabel yang dilakukan analisis mutivariat adalah usia, jenis syok, skor vasoaktif-inotropik, skor PRISM III dan fluid overload. Terdapat perbedaan hasil antara analisis bivariat dan multivariat, dimana variabel usia $<1$ tahun, jenis syok sepsis, skor vasoaktif-inotropik $\geq 20$, skor PRISM III $\geq 8$, dan fluid overload $\geq 10 \%$ secara statistik signifikan dalam meningkatkan mortalitas pasien anak dengan syok. Hasil analisis multivariat menunjukkan hanya fluid overload $\geq 10 \%$, skor PRISM III $\geq 8$, dan skor vasoaktif-inotropik $\geq 20$ yang berpengaruh signifikan terhadap mortalitas. Hasil analisis multivariat menunjukkan bahwa variabel fluid overload $\geq 10 \%$, skor PRISM III $\geq 8$, dan skor vasoaktif-inotropik $\geq 20$ pada pasien anak dengan syok dapat menjadi prediktor mortalitas yang baik. Keterbatasan penelitian ini adalah penggunaan metode retrospektif dengan mengambil data dari rekam medis. Kelengkapan data yang dimasukkan dalam penelitian tergantung pada kelengkapan data pada rekam medis. Jumlah subjek dalam penelitian masih belum memadai untuk mendapatkasn hasil yang lebih presisi. Hal ini terlihat dari hasil analisis multivariat yang memiliki rentang confiden interval yang lebar.

\section{Kesimpulan}

Skor vasoaktif-inotropik $\geq 20$, skor PRISM III $\geq 8$, dan fluid overload $\geq 10 \%$ merupakan faktor risiko mortalirtas pasien anak dengan syok. Penelitian selanjutnya dengan menggunakan variabel lebih bervariasi dan jumlah subjek lebih banyak diperlukan untuk mengetahui faktor-faktor yang memengaruhi mortalitas pasien anak dengan syok.

\section{Daftar pustaka}

1. Huang M-Y, Chen C-Y, Chien J-H, Wu K-H, Chang Y-J, Wu K-H, dkk. Serum Procalcitonin and Procalcitonin Clearance as a Prognostic Biomarker in Patients with Severe Sepsis and Septic Shock. Biomed Res Int 2016;2016:1-5.

2. De Backer D, Biston P, Devriendt J, Madl C, Chochrad D, Aldecoa C, dkk. Comparison of Dopamine and Norepinephrine in the Treatment of Shock Daniel. N Engl J Med 2010;362:779-89.

3. Awad HH, Anderson FA, Gore JM, Goodman SG, Goldberg RJ. Cardiogenic shock complicating acute coronary syndromes: insights from the global registry of acute coronary events. Am Heart J 2012;163:963-71.

4. Jawad I, Lukšić I, Rafnsson SB. Assessing available information on the burden of sepsis: global estimates of incidence, prevalence and mortality. J Glob Health 2012;2:1-9.

5. Pasman EA. Shock in pediatrics: background, pathophysiology, etiology. Dalam: Corden TE, penyunting. Medscape 2015 [dikutip 12 Juni 2018]. Didapat dari: https:/lemedicine. medscape.com/article/1833578-overview\#showall

6. Vijayamohan V. Clinical profile of shock in children in a tertiary care hospital, disertasi. Chennai: The Tamilnadu Dr.M.G.R. Medical University Madurai Medical College; 2011.

7. Mbevi G, Ayieko P, Irimu G, Akech S, English M, Ng'arng'ar $S$, dkk. Prevalence, aetiology, treatment and outcomes of shock in children admitted to Kenyan hospitals. BMC Med 2016;14:1-8.

8. Kaur G, Vinayak N, Mittal K, Kaushik JS, Aamir M. Clinical outcome and predictors of mortality in children with sepsis, severe sepsis, and septic shock from Rohtak, Haryana: A prospective observational study. Indian J Crit Care Med 2014;18:437-41.

9. Chang P, Hsu HY, Chang MH, Lin FY. Shock in the pediatric emergency service: five years' experience. Acta Paediatr Taiwan 1999;40:9-12.

10. Rusmawatiningtyas D, Nurnaningsih N. Mortality rates in pediatric septic shock. Paediatr Indones 2017;56:304-10.

11. Kim YS, Sol IS, Kim MJ, Kim SY, Kim JD, Kim YH, dkk. Serum albumin as a biomarker of poor prognosis in the 
pediatric patients in intensive care unit. Korean J Crit Care Med 2017;32:347-55.

12. Bramantyo TB, Martuti S, Salimo H. Perbandingan prediktor mortalitas Skor PRISM III dan PELOD 2 pada anak sakit kritis non bedah. Sari Pediatri 2018;19:284-9.

13. Haque A, Siddiqui NR, Munir O, Saleem S, Mian A. Association between vasoactive-inotropic score and mortality in pediatric septic shock. Indian Pediatr 2015;52:311-3.

14. McIntosh AM, Tong S, Deakyne SJ, Davidson JA, Scott HF. Validation of the vasoactive-inotropic score in pediatric sepsis. Pediatr Crit Care Med 2017;18:750-7.

15. Schwarz, AJ. Shock in pediatrics. Medscape. Corden TE, penyunting. Diunduh tanggal 16 Desember 2011. Didapat dari: emedicine.medscape.com/article/1833578-overview.

16. Medjo B, Vunjak N, Atanaskovic-Markovic M, Rsovac S, Nikolic D, Kalanj J, dkk. Indications and complications of mechanical ventilation in pediatric intensive care unit patients. Dikutip 17 September 2018 Didapat dari: https://adc.bmj.com/ content/93/Suppl_2/ps491.

17. Delgado I, Raszynski A, Totapally BR, Raszynski A, Totapally $\mathrm{BR}$, Hon KLE. Inotropes, absolute monocyte counts and survival of children with septic shock. Hong Kong J Paediatr 2016;21:22-6.

18. Claure-Del Granado R, Mehta RL. Fluid overload in the ICU: Evaluation and management. BMC Nephrol 2016;17:1-9. 